\section{Правовая природа актов ОВПБ ЕС: на примере актов Совета ЕC}

\section{Кочин И.А. ${ }^{*}$}

В настоящее время продолжается непрерывный процесс поиска новых правовых параметров отношений ЕС и РФ на перспективу. Исходя из обозначенного сторонами уровня отношений как стратегического партнерства, важно как можно скорее выработать и принять новый международный договор-Соглашение о партнерстве и сотрудничестве-2. Это позволит укрепить двусторонние отношения сторон и придать им более качественный импульс развития, а главное - определить более четкие правовые основы для успешного функционирования всего комплекса наших экономических, культурных, торговых, научных, политических и иных отношений с ЕС.

За последние годы ЕС и РФ по итогам Санкт-Петербургского саммита признали необходимым также сотрудничество в построении общих новых четырех пространств. Одним из них стала утвержденная 10 мая 2005 г. в Москве Президентом России В.В. Путиным «дорожная карта» по общему пространству внешней безопасности. В данном документе говорится: «Россия и Европейский союз признают, что процессы регионального сотрудничества и интеграции, в которых они участвуют и которые основаны на суверенных решениях государств, играют важную роль в укреплении безопасности и стабильности. Следует активно продвигать эти процессы взаимовыгодным образом посредством ориентированного на результат тесного сотрудничества и диалога. Россия и ЕС разделяют ответственность за поддержание международного порядка, основанного на эффективной многосторонности» ${ }^{1}$.

Президент России В.В. Путин справедливо отмечает: «Россия и по своему духу, и по историческим, культурным традициям является естественной частью «европейской семьи». Мы не ставим перед собой задачу присоединения к ЕС. Но, задумываясь о долго${ }^{*}$ Кочин Игорь Александрович - соискатель КГУ им. Ульянова, ст.преподаватель кафедры европейского и международного права ННГУ им. Н.И. Лобачевского, Нижегородская Областная коллегия адвокатов, адвокатская контора № 9.

${ }^{1}$ www.kremlin.ru временной перспективе наших отношений с ЕС, мы не видим областей, «закрытых» для равноправного стратегического партнерства партнерства, основанного на общих устремлениях и ценностях» ${ }^{2}$.

С учетом изложенного автор данной статьи полагает целесообразным обратиться к вопросу определения правовой природы актов общей внешней политики и политики безопасности ЕС (ОВПБ ЕС), что представляется актуальным прежде всего в контексте построения рамок нашего сотрудничества с ЕС в области общего пространства внешней безопасности.

По мнению автора, понимание специфики, особенностей природы и содержания актов ОВПБ ЕС не только позволяет обосновывать дипломатические действия ЕС на международной арене в целом, но и содействует выработке тех или иных подходов к решению ключевых международных проблем и вопросов, которые могут стать предметом обсуждения и переговоров в форме как двусторонних, так и многосторонних встреч и диалога, в том числе с участием России.

Известно, что сам термин «общая внешняя политика и политика безопасности ЕС» впервые стал общеупотребимым с момента вступления в силу «Договора о ЕС» 1992 г. ${ }^{3}$. Положения по ОВПБ содержатся в отдельной главе V Договора о ЕС. ОВПБ выступает в качестве самостоятельной отдельной сферы межправительственного сотрудничества государств - членов ЕС и применительно к ст. 2 Договора о ЕС рассматривается прежде всего как одно из средств, позволяющих утвердить индивидуальность ЕС на международной арене. В правовом порядке ОВПБ (вторая опора), которая также связана с режимом внешних сношений ЕС (общая торговая политика, гуманитарная помощь и содействие развитию) предметом правового регулирования первой опоры и посредством другого договора - Римского договора 1957 года, учредившего Европейское Сообщество, можно выделить элементы автономии ОВПБ ЕС:

- во-первых, ст. 11 Договора о ЕС ${ }^{4}$ устанавливает собственные специальные цели ОВПБ;

${ }^{2}$ Авторская статья Президента России В.В. Путина «Через партнерство России и ЕС - к строительству единой Европы, к новым возможностям для всех европейцев». 23.11.2906/www.kremlin.ru/.

${ }^{3}$ Единый Европейский Акт, Договор о ЕС // Документы ЕС. Малая библиотека ЕС на русском языке / Под ред. Ю.А. Борко. М: Право, 1994. Т. 2.

${ }^{4}$ Консолидированная версия Договора о Европейском союзе и Договора, учреждающего Европейское Сообщество / Документы ЕС. Малая библиотека ЕС на русском языке / Под ред. Ю.А. Борко. М.: Интердиалект, 2001. Т 6. 
- во-вторых, ст. 12 Договора о ЕС определяет собственные правовые инструменты (акты) ОВПБ;

- в-третьих, ОВПБ располагает собственными институциональными структурами, такими как: председательствующее в Совете ЕС государство (ст. 18 Договора о ЕС); высокий представитель по ОВПБ/ генеральный секретарь Совета ЕС (ст. 18 п. 3 и ст. 26 Договора о ЕС); специальный представитель, который может быть назначен Советом ЕС для выполнения конкретной миссии (ст. 18 п. 5 Договора о ЕС); комитет по вопросам политики и безопасности (ст. 25 Договора о ЕС);

- в-четвертых, развитие общей оборонительной политики ЕС в качестве составного компонента ОВПБ.

Договор о ЕС устанавливает, что решения по вопросам ОВПБ принимает Совет ЕС. Актами Совета ЕС по ОВПБ являются совместные действия (ст. 14 Договора о ЕС) и общие позиции (ст. 15 Договора о ЕС).

С момента вступления в силу Договора о ЕС Совет ЕС в рамках ОВПБ на основании ст. Ј.2 (ст. 15 Договора о ЕС) принял целую серию «общих позиций».

Первоначально не было четкого разграничения между «общими позициями» и «совместными действиями» как формами решений Совета ЕС по ОВПБ. С целью определения того, что же следует понимать под «общими позициями», Совет ЕС принял отдельный документ ${ }^{5}$, основываясь на котором «общие позиции» могли представлять собой «стратегии» или «ориентиры» по отношению к третьим странам или касаться многосторонних вопросов. Другой документ Совета ЕС ${ }^{6}$ указывал, что «общие позиции» позволяют Союзу определять политическую позицию, устанавливая общие принципы и приоритеты Союза по всем аспектам политических и экономических отношений Союза с определенной третьей страной.

Впоследствии, в редакции Амстердамского договора 1997 г. ст. 15 Договора о ЕС, заменившая прежнюю редакцию нормы ст. Ј. 2, стала более определенной в правовом контексте: «Общие позиции определяют подход Союза по определенному вопросу географического и тематического характера».

Однако, как и прежде, сам текст договора не содержит каких-либо критериев того, что же следует понимать под данной формулировкой:

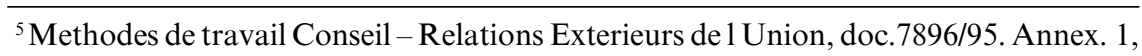
adopted by the General Affairs Council, 12 June 1995.

${ }^{6}$ Mode d' emploi concernant les positions communes definies sur la base de l' article J.2 du Traite sur l' Union Europeenne, Doc. 5194/95. «вопросы географического или тематического характера».

Ситуация несколько проясняется, если мы вспомним о роли Европейского Совета, который и призван зафиксировать границы ОВПБ, определяя главные принципы и основные ориентиры в деятельности ОВПБ (ст. 13 п. 3 Договора о ЕС).

Начиная с Маастрихта на практике «принципы и основные ориентиры» - это любые значимые «заключения» Европейского Совета, а не обязательно какие-то специально разрабатываемые тексты. В заключениях Европейского Совета в Лиссабоне (26-27 июня 1992 г.) определяется понятие «общих интересов». Оно является необходимым условием принятия Советом ЕС «общей позиции», и выделяется ограниченное число географических зон (страны Центральной и Восточной Европы, Балканы, территория бывшего СССР, страны Средиземноморья, Африка и Ближний Восток) в отношении которых возможно применить «общую позицию» ЕС. В заключениях Европейского Совета в Копенгагене (21-22 июня 1993 г. $)^{8}$ говорится о необходимости формулирования «общей позиции» со странами/регионами, рискующими затронуть стабильность в Европе (бывшая Югославия, Украина, Северная Африка). Подобный подход расставлять акценты в сфеpax ОВПБ обнаруживается в большей части заключений Европейского Совета, в том числе в приложениях к ним. Так, например, Восточной Европе посвящено приложение IV, а странам Средиземноморья приложение V заключений Европейского Совета в Эссене (9-10 декабря, 1994 г.)

Другими словами, в заключениях Европейского Совета содержатся главные принципы, касающиеся стратегии, которой придерживается ЕС в отношениях с различными зонами земного шара: Восточной Европой, странами Средиземноморья, Азией, Латинской Америкой и т.д.

Следует заметить, что Амстердамским договором 1997 г. в систему инструментов ОВПБ была включена «общая стратегия», которая также принимается Европейским Советом по принципу единогласия (п. 2 ст. 13 Договора о ЕС) и осуществляется ЕС в областях, где у государств - членов ЕС есть общие важные интересы. «Общая стратегия» позволяет ускорить процедуру принятия решений по ОВПБ («общих позиций» и «совместных действий») на основе использования принципа голосования квалифицированным большинством.

\footnotetext{
${ }^{7}$ www.europa.eu./european_council/conclusions/index_en.htm
}

${ }^{8}$ Там же. 
Не умаляя ключевой роли Европейского Совета в определении политики на высшем уровне, необходимо помнить, что придание конкретной материальной основы такой политике - это роль Совета $\mathrm{EC}$, поскольку именно он «принимает решения, необходимые для осуществления ОВПБ, исходя из основных ориентиров, определенных Европейским Советом либо на основе принятой им «общей стратегии».

Как мы уже отметили ранее, основными формами решений по ОВПБ, которые принимает Совет ЕС, являются «общие позиции» (ст. 15 Договора о ЕС) и «совместные действия» (ст. 14 Договора о ЕС).

«Общие позиции» были одним из инструментов механизма европейского политического сотрудничества и до принятия Договора о ЕС. Упоминание о них содержится в главе III Единого Европейского Акта 1986 года9 ${ }^{9}$ Правовая природа «общих позиций» как актов ОВПБ выражается в норме п. 2 ст. 15 Договора о ЕС: «Государства - члены ЕС гарантируют, что их национальные политики соответствуют общим позициям». И, наконец, п. 1 ст. 19 Договора о ЕС гласит: «Государства-члены должны координировать свои действия в международных организациях и на международных конференциях, поддерживая «общие позиции».

В международных организациях и на международных конференциях, где участвуют не все государства-члены, те государства, которые участвуют, должны придерживаться общих позиций».

Следовательно, как отмечает Вессел ${ }^{10}$, «общие позиции», с одной стороны, требуют от государств-членов сделать что-то (привести национальные политики в соответствие с «общей позицией»), а с другой - воздержаться от каких-либо действий (не принимать каких-либо национальных позиций, которые не соответствуют «общей позиции»).

Собственный анализ работ специалистов европейской школы права, а также опубликованных в Официальном журнале ЕС «общих позиций» позволяет автору настоящей статьи сделать вывод о том, что «общие позиции» базируются на принципе лояльности и взаимной солидарности государств - членов ЕС и могут быть подразделены на следующие категории:

${ }^{9}$ Единый Европейский Акт, Договор о ЕС / Документы ЕС. Малая библиотека ЕС на русском языке / Под ред. Ю.А. Борко. М: Право, 1994. Т. 2.

${ }^{10}$ Wessel R.A. European Union s Common Foreign and Security Policy. A Legal Institutional Perspective. Kluwer Law International, 1999.
1) решения о политике ЕС по отношению к третьему государству;

2) решения о применении санкций в отношении третьих государств;

3) решения о политике ЕС по специальному вопросу.

Во всех случаях государства - члены ЕС являются управляемыми «общими позициями», которым им надо следовать обязательно как заданному маршруту: уважать их в рамках выработки национальной политики. Кроме того, «общие позиции» не только в определенной степени ограничивают суверенитет государств-членов ЕС, но также связывают и Совет ЕС, который их принимает исходя из своих убеждений. «Общие позиции» в равной степени оказывают влияние и на действия других институтов ЕС, и прежде всего Европейской Комиссии, ответственной за внешние отношения ЕС.

Будучи упомянутой в «общей позиции», принятой Советом ЕС на основании ст. 15 Договора о ЕС, Европейская комиссия ограничивается на соответствующих направлениях своей деятельности в отношении отдельных стран мира, исходя из содержания такой «общей позиции».

С момента запуска режима ОВПБ Договором о ЕС специалисты в области европейского права неоднократно отмечали необходимость реформирования модели ОВПБ ЕС с целью придания ОВПБ большей эффективности, совершенствования работы институтов ЕС, задействованных в работе по ОВПБ, выработке последовательности и единства между деятельностью Совета ЕС и Европейской Комиссии в данном направлении. Указанная задача частично решалась принятием Амстердамского договора 1997 г., Ниццского договора 2001 г., разработкой проекта договора, устанавливающего Конституцию для ЕС (2004 г.).

По мнению автора данной статьи, с целью лучшего понимания правовой природы «общей позиции» следует привести конкретные примеры выделенных категорий актов вторичного права ЕС.

Первая категория - решения о политике ЕС по отношению к третьему государству. Пример - общая позиция Совета ЕС на основе ст. Ј.2, касающаяся целей и приоритетов ЕС по Руанде (решение 94/697/ОВПБ Совета ЕC) ${ }^{11}$. В данном случае речь идет о попытке сформулировать глобальную стратегию по отношению к третьим странам, находящимся в кризисе. Сформулированные цели и приоритеты касаются возвращения беженцев и национального примирения. Другие цели и приоритеты ЕС прослеживаются в идее гуманитарной помощи, содействия

\footnotetext{
${ }^{11}$ Council Decision 94/697/CFSP, Official Journal L/283 от 29.10.1994 г.
} 
развитию и значимости ответа перед правосудием лиц, ответственных за грубые нарушения прав человека, в частности геноцид.

Вторая категория - решения о применении санкций в отношении третьих государств. Правовой основой принятия «общих позиций» подобного рода становилась ст. Ј.2 Договора о ЕС во взаимосвязи со ст. 228 А и ст. 73 G Римского договора 1957 г. Это касалось ситуации когда «общая позиция» в рамках ОВПБ предусматривала действия со стороны Сообщества по ограничению или прекращению вообще или частично экономических отношений с одной или несколькими третьими странами. Было время, когда акты Сообщества в этой сфере должны были быть зафиксированы в соответствии с регламентом ЕС по ст. 113 Римского договора и по решениям ЕОУС, дополненным решениями правительств государств - членов ЕС, объединенных в Совете ЕС (экономические санкции в отношении ЮАР, Ирака и Сирии).

Однако со вступлением в силу Маастрихтского договора Совет ЕС принял целую серию «общих позиций» во взаимосвязи со ст. 228 А Римского договора. Большинство этих решений соотносилось с резолюциями СБ ООН, которыми предусматривалось введение экономических санкций.

Наиболее известные примеры:

- Ливия: решение Совета ЕС 93/614/ОВПБ о прекращении экономических отношений от 22 ноября 1993 г. $^{12}$

- Судан: решение Совета ЕС 94/165/ОВПБ об эмбарго оружия и боеприпасов и военного оборудования от 15 марта 1994 г. ${ }^{13}$;

- Гаити: решение Совета ЕС 94/315 ОВПБ о прекращении экономических отношений от 30 мая 1994 г. $^{14}$, в дальнейшем дополненное решением Совета ЕС 94/681/ОВПБ от 14 октября 1994 г. ${ }^{15}$

- Бывшая Югославия: решение Совета ЕС 94/366/ОВПБ об эмбарго торговых отношений в развитие резолюции СБ ООН 757 (1992) от 13 июня 1994 г. ${ }^{16}$, в дальнейшем дополненное решением Совета ЕС 94/672/ОВПБ о прекращении экономических и финансовых отношений с отдельными частями территории Республики Босния и Герцеговина, находящихся под контролем сербо-боснийских сил и решением

${ }^{12}$ Council Decision 93/614/CFSP, Official Journal L/295 от 13.11.1993 г.

${ }^{13}$ Common Position 94/165/CFSP, Official Journal L/75 от 17.03.1994 г.

${ }^{14}$ Council Decision 94/315/CFSP, Official Journal L/139 от 2.06.1994 г.

${ }^{15}$ Council Decision 94/681/CFSP, Official Journal L/271 от 21.10.1994 г.

${ }^{16}$ Common Position 94/366/CFSP, Official Journal L/165 от 1.07.1994 г.
Совета ЕС 94/673/ОВПБ от 10 октября 1994 г. по Федеративной Республике Югославия (Сербия и Черногория) $)^{17}$.

Так, в частности, из содержания решения Совета ЕС 94/315/ОВПБ следует: «Экономические отношения с Гаити будут ограничены согласно соответствующим положениям мандата СБ ООН и принятой им резолюции 917 (1994); государства - члены ЕС должны без промедления принять законы, регламенты или административные меры, необходимые для того, чтобы заморозить фонды и финансовые ресурсы, упоминаемые в п. 4 резолюции СБ ООН 917».

В решении Совета ЕС 94/672/ОВПБ говорится: «Экономические и финансовые отношения должны быть ограничены с теми частями территории Республики Босния и Герцеговина, которые находятся под контролем боснийских сербов, согласно принятой СБ ООН резолюции 942 (1994).

Третья категория - решения о политике ЕС по специальному вопросу.

Специальных международных вопросов касается ограниченное число принятых Советом ЕС общих позиций. Цель подобных решений установить общую политику государств - членов ЕС в ходе проходящих или планируемых переговоров по заключению международных договоров. Пример - Общая позиция 95/379/ОВПБ от 18.09.1995 г. в отношении ослепляющих лазеров ${ }^{18}$, в которой Совет ЕС решил, что «государства - члены ЕС должны активно содействовать принятию дополнительного протокола к Конвенции по ослепляющим лазерам 1980 г.» ругой пример - Общая позиция 2006/242/ОВПБ ${ }^{19}$, предметом которой является общая стратегия на переговорах в рамках международной конференции по Конвенции о бактериологическом и химическом оружии.

В этом смысле «общие позиции» можно рассматривать в качестве инструмента гармонизации действий государств - членов ЕС с целью достижения соглашения на переговорах.

Можно также встретить и другую разновидность - это общие позиции по специальным вопросам определенного географического характера. Например, общие позиции по предотвращению конфликта и урегулированию в Африке, в которых говорится о правах человека,

${ }^{17}$ Council Decision 94/672/CFSP, Council Decision 94/ 673/CFSP от 10.10.1994 г, Official Journal L/266 от 15.10 .1994 г

${ }^{18}$ Common Position 95/379/CFSP, Official Journal L/227 от 18.09.1995 г.

${ }^{19}$ Common Position 2006/242/CFSP, Official Journal L/88/65 от 25.03.2006 г. 
демократических принципах, верховенстве права в Африке: Общая позиция 98/350/ОВПБ от 25.05.1998 г. ${ }^{20}$, а также общая позиция 2000/420/ОВПБ ${ }^{21}$, касающаяся поддержки ЕС усилий Организации Африканского Единства в мирном урегулировании конфликта междуЭфиопией и Эритреей. Похожие решения - по содействию нераспространению ОМУ и мерам доверия в Южно-Азиатском регионе, процессу стабильности и добрососедства в Юго-Восточной Европе (Общая позиция 98/606/ОВПБ от 26.10.1998 г. ${ }^{22}$ ).

Автор статьи полагает, что применительно к природе большинства «общих позиций» как актов ОВПБ ЕС можно вести речь о «решениях особого рода (sui generis)». Обоснование указанной точки зрения будет дано автором в общих выводах статьи.

O «совместных действиях» впервые упоминала ст. 30 п. 2 Единого Европейского Акта 1986 г. Данная норма предусматривала, что «совместное действие» - одно из средств «гарантировать как можно более эффективное осуществление совместного влияния Высоких Договаривающихся Сторон».

Природа «совместных действий» как акта ОВПБ с принятием и вступлением в силу Договора о ЕС, как указывает Вессел ${ }^{23}$, изменилась. Ранее в период действия внедоговорного механизма европейского политического сотрудничества это была своего рода «международная акция государств - членов ЕС на основе добровольного сближения ad hoc национальных политик. Это было не отдельное решение, а скорее результат принятой «общей позиции».

Применительно же к содержанию нормы ст. 14 Договора о ЕС «совместное действие» приобретает обязательную силу, поскольку ст. 14 п. 3 Договора о ЕС гласит: «Совместные действия должны связывать государства - члены ЕС в тех позициях, что они принимают и в их деятельности».

Другими словами, они ограничивают свободу государств - членов ЕС в их индивидуальных политиках. Государствам - членам ЕС не разрешается принимать позиций или действовать вопреки принятому «совместному действию». Более того, они обязуются проводить свои

${ }^{20}$ Common Position 98/350/CFSP, Official Journal L/158 от 02.06.1998 г.

${ }^{21}$ Council Common Position 2000/420/CFSP, Official Journal L/161 от 01.07.2000 г.

${ }^{22}$ Common Position 98/606/CFSP, Official Journal L/290 от 29.10.1998 г.

${ }^{23}$ Wessel R.A. The European Union' s Common and Security Policy. Kluwer Law International, 1999. национальные политики в соответствии с согласованными «совместными действиями».

Маклеод, Хендри и Хайет ${ }^{24}$ полагают, что иногда «совместные действия» следует рассматривать как «решения Совета ЕС особого рода (sui generis), которые имеют силу и регулируются международным правом».

Виллаэрт и Маркюз-Рюиз ${ }^{25}$, рассуждая о природе «совместных действий», говорят, что «совместные действия независимо от их содержания возлагают на государства - члены ЕС обязательство действовать в соответствии с ними».

В свою очередь Вессел говорит даже «о возможном сравнении «совместных действий» как актов, принимаемых Советом ЕС, с решениями

СБ ООН, обязательная сила которых независимо от их текстового содержания определяется нормой ст. 25 Устава ООН».

Решения основанные на ст. 14 Договора о ЕС («совместные действия〉) - это нормы, требующие определенного безусловного поведения от государств - членов ЕС. Возможное отступление от этого, допустимо в качестве исключения из общего правила, о чем свидетельствует ст. 14 п. 2 Договора о ЕС. Однако, и в этом случае, последнее слово остается за Советом ЕС. Вместе с тем, правовой анализ содержания Договора о ЕС показывает, что существует также и правило нормы ст. 14 п. 6 Договора о ЕС, позволяющее государствам - членам ЕС отступить от их обязательств, вытекающих из «совместного действия». Следует отметить и тот факт, что само по себе принятие Советом ЕС «совместного действия» не лишает государств - членов ЕС возможности принимать национальные политические инициативы по вопросу в той же области.

Применительно к общей характеристике данного правового акта ОВПБ можно отметить, что «совместные действия» могут включать меры по поддержке государствами - членами ЕС определенной деятельности в третьих странах; другая категория «совместных действий» касается общих международных политик ЕС; следующая их категория может подразумевать гармонизацию национальных политик государств - членов ЕС. В последнее время «совместные действия» также

${ }^{24}$ MacLeod I., Hendry I.D. and Hyett S. The External Relations of the European Communities: A Manual of Law and Practice. Oxford: Clarendon Press, 1996.

${ }^{25} \mathrm{Willaert} \mathrm{Ph}$. and C.Marques- Ruiz. Vers une politique entrangere et de securite commune etat des lieux. Revue du Marche Unique Europeen, 1995. No. 3. P. 35-95. 
используются для обоснования проведения ЕС военных и гражданских операций в рамках становления общей европейской политики безопасности и обороны (ОЕПБО).

Примерами первой категории «совместных действий» являются: общая политика поддержки ЕС демократического развития в определенной третьей стране (поддержка правительства Монтенегро ${ }^{26}$ ). Часто «совместные действия» используются в качестве правовой основы назначения и продления мандата специальных представителей ЕС (на Ближний Восток ${ }^{27}$, Центральную Азию ${ }^{28}$, Молдавию $^{29}$, Боснию и Герцеговину ${ }^{30}$, Южный Кавказ $\left.{ }^{31}\right)$.

С момента вступления в силу Маастрихтского договора Совет ЕС на основании ст. Ј.3 предпринял ряд «совместных действий». Пять из первых девяти рассматривались как приоритетные действия в соответствии с общими направлениями Европейского Совета от 29.10.1993 г. в области международных отношений и в области общей внешней политики и политики безопасности. Некоторые из них уже закончены, некоторые еще продолжают действовать или были продлены ${ }^{32}$.

А. Пакт о стабильности в Европе.

Решения Совета ЕС 93/728/ОВПБ от 20.12.1993 г. и 94/367/ОВПБ от 14.06.1994 г. (продление)

Это совместное мероприятие, основанное на инициативе Франции и названное по имени премьер-министра Франции «Планом Баладюра», было предусмотрено Лиссабонскими решениями Европейского Совета (1992 г.). Этот план основан на подходе превентивной дипломатии, исходящей из принципа «лучше предупредить, чем лечить».

В ходе своих заседаний 29.10.1993 г. и 10-11.12.1993 г. (Брюссель) Европейский Совет воспринял эту идею и предложил Совету ЕС принять «совместное действие» в рамках ст. Ј.3 договора. Это предложение было принято во внимание и реализовалось в решении Совета 93/728/ОВПБ от 20.12.1993 г. ${ }^{33}$

${ }^{26}$ Joint Action 98/301/CFSP, Official Journal L/138 от 09.05.1998 г.

${ }^{27}$ Council Joint Action 2003/873/CFSP, Official Journal L/326 от 13.12.2003 г.

${ }^{28}$ Council Joint Action 2005/588/CFSP, Official Journal L/199 от 29.07.2005 г.

${ }^{29}$ Council Joint Action 2005/265/CFSP, Official Journal L/81 от 30.03.2005 г.

${ }^{30}$ Council Joint Action 2006/49/CFSP, Official Journal L/26 от 31.01.2006 г.

${ }^{31}$ Council Joint Action 2006/121/CFSP, Official Journal L/49 от 21.02.2006 г.

${ }^{32}$ La Politique Entrangere et de Securite Commune(PESC). Dossier constitue par Dominique Fabre, professeur associe a l'Institut d'etudes politiques de Lille. No.775-776, 22 novembre 1996.

${ }^{33}$ Council Joint Action 93/728/CFSP, Official Journal L/339 от 31.12.1993 г.
Совместное действие предусматривало, что подготовительной фазой станет созыв конференции о заключении Пакта о стабильности в Европе в Париже в 1994 г. Решения этой конференции зафиксированы в приложении к решениям Совета ЕС 94/367/ОВПБ от 14.06.1994 г. ${ }^{34}$, которые продлевают сотрудничество. Заключительный документ напоминает о целях и принципах этой вступительной конференции и содержит оперативные решения, предусматривающие проведение серии двусторонних и региональных переговоров (переговоры типа «круглый стол») между вышеупомянутыми государствами и Евросоюзом.

Б. Контроль за выгорами в России.

Решение Совета ЕС 93/604/ОВПБ от 20.11.1993 г.

12 декабря 1993 г. граждане Российской Федерации были призваны проголосовать за новую Конституцию и выбрать двухпалатный Парламент. Этому событию предшествовали беспорядки 3-4 октября 1993 г. Учитывая шаткую политическую ситуацию, многие международные организации, такие как СБСЕ и Совет Европы, решили отправить в Россию наблюдателей с целью поддержать своим присутствием существующие демократические силы и следить за правильным ходом этих важных выборов; СБСЕ отправил 500 наблюдателей. Союз прибег к этой инициативе, основываясь на решении Совета ЕС 93/604/ОВПБ от 09.11.1993 г. ${ }^{35}$

Союз отправил группу экспертов и дипломатов - двенадцать представителей Комиссии, к которым присоединилась и делегация Европейского Парламента. Оценку оглашенных результатов выборов, международные наблюдатели, в числе которых группа Евросоюза, сделали темой совместного доклада, не являющегося общедоступным. В немецкой газете (FAZ от 06.05.1994 г.) можно было прочесть, что газета «Известия» опубликовала искаженные результаты выборов, однако статья в немецком издании основана на непроверенных фактах.

В заключение можно сказать, что это первое совместное действие дало интересный опыт для ОВПБ; Совет Европы смог извлечь выгоду из этого опыта в ходе схожих по своей природе совместных действий, проведенных позднее (Южная Африка и Мозамбик). Лицом к лицу с иностранными государствами Евросоюз стал приобретать таким образом политический профиль.

${ }^{34}$ Council Joint Action 94/367/CFSP, Official Journal L/165 от 01.07.1994 г. ${ }^{35}$ Council Joint Action 93/604/CFSP, Official Journal L/286 от 20.11.1993 г. 
В. Бывишая Югославия.

Гуманитарное содействие в Боснии и Герцеговине (1993-1994 гг.).

Решения Совета ЕС 93/603/ОВПБ от 08.11.1993 г., 93/729/ОВПБ от 20.12.1993 г., 94/158/ОВПБ от 07.03.1994 г. и 94/789/ОВПБ от 12.12.1994 г. (продление).

Речь идет о продолжении выделения гуманитарной помощи, которую Евросоюз оказывал с начала югославского конфликта. Эта поддержка заключалась в 1991 г. в продовольственной помощи. Природа помощи была разнообразна и охватывала все области гуманитарного содействия (продовольственную, жилищную, медицинскую, санитарную, социальную, восстановление инфраструктуры). Ею управляла в основном дирекция Комиссии “ЕCHO”, которая обращалась за исполнением относительно Боснии и Герцеговины к организациям, входящим в систему ООН, особенно к Верховному Комиссару ООН по делам беженцев (UNHCR). C конца 1992 г. специальная оперативная группа государств - членов Европейского Сообщества, базировавшаяся в Загребе (Хорватия), была учреждена с целью лучшего управления различными видами помощи. Оперативная группа Европейского Сообщества была предшественником «совместных действий» в рамках ОВПБ (ст. Ј.3 Договора о ЕС). С введением в действие Договора о ЕС оперативная группа Европейского Сообщества была удачно включена в рамки ОВПБ; что отражено в параграфе 3 решения Совета ЕС 93/603/ОВПБ от 08.11.1993 г.

Кроме того, решение Совета ЕС 93/603/ОВПБ от 08.11.1993 г. учитывает в параграфе 5 политическую значимость этого мероприятия (ссылка сделана на лорда Оуэна $)^{36}$.

Управление Евросоюзом городом Мостар.

Решения Совета ЕС 94/308/ОВПБ от 01.05.1994 г. и 94/510/ОВПБ от 27.07.1994 г. и 94/790/ОВПБ от 12.12.1994 г. (продление).

В рамках процедур ОВПБ ЕС и основываясь на направленности, взятой из контекста международных переговоров, Евросоюз решил внести свой вклад в мирное урегулирование конфликта в Бывшей Югославии посредством добрых услуг, предусматривающих управление Евросоюзом города Мостара в Боснии и Герцеговине.

Этот город в течение нескольких месяцев был центром напряженных боев между хорватским и мусульманским населением. 28 марта ${ }^{36}$ На тот момент лорд Оуэн был специальным представителем Сообщества в числе посредников ООН (Архив Собрания Французского законодательства 1994 г.)
1994 г. на сессии Европейского Совета, собранной в Иоании (Греция) депутат Бундестага Германии Кочник был назначен управляющим Мостаром. Предварительно, на согласительном меморандуме с властями города были оговорены условия этой специальной миссии, которая в любом случае могла иметь лишь временный характер. Решение Совета ЕС 94/308/ОВПБ от 16.05.1994 Г ${ }^{37}$, было дополнено решением Совета ЕС 94/510/ОВПБ от 27.07.1994 $\Gamma^{38}$.

Выделенные денежные средства должны были пойти на финансирование разрушенных инфраструктур (в частности, водоснабжение, электричество) и предварительное восстановление линий коммуникации (мосты) между двумя частями города. Одному из органов Европейского Союза было поручено снарядить полицейскую силовую группу с целью улучшения материально-хозяйственных функций и обеспечения определенной безопасности миссии Евросоюза в г. Мостаре. Продолжительность миссии была определена в два года ${ }^{39}$.

Таким образом, нормальный ход этой миссии позволил бы Евросоюзу демонстрировать утверждение своей индивидуальности на международной арене.

Г. Мирный процесс на Ближнем Востоке.

Решение Совета ЕС 94/276/ОВПБ от 19.04.1994 г.

Приведенный в действие с 1991 г. мирный процесс на Ближнем Востоке в ходе Мадридской конференции, проходившей под покровительством США и СССР, приобрел для Сообщества, а в дальнейшем для Евросоюза первоочередную важность. С тех пор посредством своих представителей, Евросоюз участвовал во всех важнейших этапах этого мирного процесса. Нужно признать, что Евросоюз не участвовал в этом процессе в качестве первостепенного участника, так как эта роль была de facto отдана США. Наконец, напомним, что мирный процесс окончился после секретных переговоров в Осло историческим договором, подписанным 13 сентября 1993 г. в Вашингтоне. Договор сопровождался конференцией международных спонсоров, имеющих целью оказать экономическую помощь палестинскому народу.

В результате этой конференции был установлен двойной подход к переговорам: первый - многосторонний, распределяющий проблемы на пять групп (водоснабжение, беженцы, окружающая среда, кон-

\footnotetext{
${ }^{37}$ Council Joint Action 94/308/CFSP, Official Journal L/134 от 30.05.1994 г.

${ }^{38}$ Council Joint Action 94/510/CFSP, Official Journal L/205 от 08.08.1994 г.

${ }^{39}$ Council Joint Action 94/790/CFSP, Official Journal L/326 от 17.12.1994 г.
} 
троль поставок оружия и региональное экономическое развитие); второй - двусторонний, касающийся в основном проблем политического характера между соседними странами (например, Израиль/Иордания, Египет/Израиль, Израиль/Сирия). Сообщество получило место председателя в рабочей группе по региональному экономическому развитию. Общее руководство международным участием осуществлялось Специальным комитетом по содействию (AHLC) ${ }^{40}$.

Следует также упомянуть Каирскую конференцию, состоявшуюся 4 мая 1994 г., которая закрепила этот процесс соглашением о палестинской автономии в Секторе Газа.

На этом фоне, Европейский Совет в Брюсселе в ходе внеочередной сессии 29 октября 1993 г. внес «мирный процесс на Ближнем Востоке» как одну из приоритетных областей в свои заключения, относящиеся к воплощению в жизнь ОВПБ, прежде чем сделать «совместные действия» заголовком ст. Ј.3 Договора о ЕС.

В ходе своей сессии 10 декабря 1993 г. Европейский Совет определяет первые «общие направления» на основании ст. Ј.3 Договора о ЕС (параграф 1), среди прочих - вопрос о мирном процессе на Ближнем Востоке.

На основе этих общих направлений Совет ЕС «По общим вопросам» принял решение 94/276/ОВПБ от 19 апреля 1994 г. ${ }^{41}$, которое стало основой «совместного действия по поддержке мирного процесса на Ближнем Востоке». Решение указывает на цели участия ЕС в международном урегулировании споров: гарантировать мир в регионе, работать над укреплением демократии, внести вклад в определение формы, которую примут отношения между частями региона и способы достижения этих целей. К тому же оно очень точно определяет области деятельности, такие как «активно участвовать в создании палестинской полиции» (ст. 3 Решения). Было заявлено, что ЕС также будет участвовать во временном присутствии международных сил ООН, которые предусматривала резолюция СБ ООН 904 (1994).

Понятно, что осуществление этого совместного действия тесно связано с «продолжением» конференции спонсоров в Вашингтоне (Касабланкская конференция 1994 г.) и развитием политических событий, которые относятся или затрагивают этот мирный процесс. Среди важнейших политических вопросов - ситуация с Иерусалимом, городом, разделенным на две части: арабскую и израильскую.

${ }^{40}$ Архив Собрания Французского законодательства 1994 г.

${ }^{41}$ Council Decision 94/276/CFSP, Official Journal L/1 19 от 07.05.1994 г.

\section{Д. Южная Африка.}

Решение Совета ЕС 93/678/ОВПБ от 6 декабря 1993 г.

29 октября 1993 г. Европейский Совет определил Южную Африку одним из приоритетных направлений совместных действий в рамках ОВПБ. Это не удивительно, так как Евросоюз хотел играть на международной арене, в основном благодаря инструментам ОВПБ, более важную роль. С другой стороны, отношения Союза с Южной Африкой известны исторически и оставались таковыми до 27 октября 1993 г., когда затронули вопрос о кодексе поведения для европейских компаний, действующих на территории Южной Африки. Напомним, что этот кодекс должен был обеспечить применение социальных норм по отношению к работникам-африканцам. Режим апартеида привел также к введению ряда торговых и экономических санкций, «негативных мер», сбалансированных «положительными мерами. Эти меры соотносились со специальной программой помощи жертвам апартеида во всех областях, начатой в 1985 г., снабженной кредитами, записанными в бюджет Европейского Сообщества, и плавно ставшей одной из наиболее значимых программ помощи в рамках международных отношений Сообщества (к ним относятся такие области, как: гуманитарная подлержка, образование, меры по переходу с военного на гражданское положение и др.). ОВПБ смогла основываться на ней в рамках новой миссии.

Во второй половине 1993 г. развитие политики в Южной Африке дало возможность задуматься о перспективе проведения первых многонациональных выборов. На этом фоне в ходе сессии 6 декабря 1993 г. в рамках ОВПБ и, основываясь на ст. Ј.3, Совет ЕС принял решение 93/678/ОВПБ ${ }^{42}$. Основная цель ЕС в нем определена как поддержка Евросоюзом процесса демократизации. Оно предусматривает две области действий:

- помощь в организации и проведении выборов посредством отправки необходимого числа наблюдателей;

- поддержка процесса политического и экономического преобразования посредством претворения в жизнь основ взаимодействия с целью укрепить экономические и социальные основы переходного периода.

Как и другие совместные действия и общие позиции, эта акция, относящаяся к Южной Африке, - широкая и глобальная, природа ${ }^{42}$ Council Decision 93/678/CFSP, Official Journal L/316 от 17.12.1993 г. 
которой заключает в себе взаимодействие с первой опорой Договора об образовании Европейского Сообщества (общая торговая политика и политика содействия).

Е. Договор о нераспространении ядерного оружия.

Решение Совета ЕС 94/509/ОВПБ от 25 июля 1994 г.

Конференция, созванная в 1995 г. в Женеве и Нью-Йорке с целью обсуждения дальнейшего действия договора о нераспространении ядерного оружия, подписанного в 1968 г. и введенного в действие 5 марта 1970 г., дала ему новое дыхание.

Основываясь на общих установках Европейского Совета, в ходе его сессий в Лиссабоне (июнь 1992 г.) и Эдинбурге (декабрь 1992 г.) Советом ЕС 25 июля 1994 г. было принято решение о совместном действии. Подход заключался в необходимости продления договора на неопределенный срок и без каких-либо условий, в приложении усилий с целью убедить государства, не присоединившиеся к договору, сделать это, и в возможности оказания помощи Евросоюзом третьим странам с расчетом на их присоединение к договору и выполнение необходимых процедур, вытекающих из обязательств, предусмотренных договором.

Ж. Совместное действие, введенное Регламентом Совета ЕС относительно контроля экспорта товаров двойного назначения.

Решение Совета ЕС 94/942/ОВПБ от 19 декабря 1994 г., а на данный момент регламент Совета ЕС № 1334/2000"43, устанавливающий режим контроля.

Институты Сообщества в течение нескольких лет работали над разработкой регламента (ЕС), основанного на ст. 113 Договора о Европейском Сообществе (общая торговая политика), чтобы найти проблемам, вызванным экспортом товаров двойного назначения (гражданское и военное предназначение), надлежащее решение. Вспоминается шумиха по поводу поставки химических продуктов и других составляющих, предназначенных для завода в Ливии и разоблачение использования этих с виду безопасных веществ. Регламент Сообщества, с одной стороны, установивший беспрепятственный оборот товаров на его территории, с другой - ставит вопрос о контроле экспорта товаров двойного назначения. Из-за преимущественной компетенции государств - членов ЕС в этой области она не могла регулироваться актом «Сообщества» в рамках ст. 113 Договора, учреждающего Евро-

${ }^{43}$ Council Regulation (EC) №1334/2000, Official Journal L/159 от 30.06.2000 г. пейское Сообщество. В связи с этим нужно было дополнить регламент Сообщества актом ОВПБ. Создание такого акта предусматривалось ст. Ј.3 Договора о ЕС как «совместное действие». Это совместное действие, касающееся политических сторон вопроса, было присоединено к регламенту, принятому Советом в ходе своих заседаний 19-20 декабря 1994 г. и вступило в силу 1 марта 1995 г. В настоящее время действует регламент ЕС №1334/2000.

3. Согласованный подход к «незаконной торговле радиоактивными вешествами».

Не то чтобы действительно совместное действие, но согласованное мероприятие в области безопасности.

Политические инстанции Евросоюза пришли к пониманию необходимости создания «согласованного подхода»; на самом деле этот феномен касается многих положений договора и задевает три его опоры: общую торговую политику ЕС и содействие сотрудничеству с третьими странами (первая опора), меры по борьбе с международной преступностью в рамках статьи К (третья опора) и политические аспекты, относящиеся к ОВПБ (вторая опора) Договора о ЕС.

В текстах «совместных действий» можно обнаружить значительное многообразие содержащих их норм: от императивных до сформулированных по большей части как нормы-цели, декларативных норм либо норм-утверждений и норм-выражений. Нормы «совместных действий» предусматривают определенный курс действий со стороны государствчленов ЕС, достижение определенного состояния дел либо выражения отношения к положению дел.

В большинстве случаев «Европейский союз», как указывается в «совместном действии», должен осуществлять конкретное действие или следовать определенному курсу. Сформулированные подобным образом положения следует рассматривать как «приказ» Совета ЕС, адресованный самому себе в первую очередь, а не государствам - членам ЕС. Например, «ЕС будет осуществлять координированную программу помощи по подготовке выборов, проходящих в Южной Африке». В другом случае с целью гармонизации национальных политик нормы «совместного действия» могут быть адресованы как ЕС, так и самим государствам - членам ЕС (например, совместное действие ЕС по противопехотным минам $\left.{ }^{44}\right)$.

${ }^{44}$ Joint Action 96/588/CFSP и Joint Action 97/817/CFSP, Official Journal L/260 от 12.10.1996 г. и L/338 от 09.12.1997 г. 
Часто «совместные действия» используются Советом ЕС и для констатации юридических фактов, включая создание специальных институтов или групп, на которые возлагается осуществление определенных функций (например, учреждение Европейского института исследований вопросов безопасности ${ }^{45}$, Европейского колледжа по вопросам безопасности и обороны ${ }^{46}$, Европейского оборонного агентства $\left.{ }^{47}\right)$.

Об этом же наглядно упоминается и в решении Совета ЕС 2000/354/ОВПБ по учреждению Комитета по гражданским аспектам урегулирования кризисов ${ }^{48}$. Оно основывается на ст. 28 п. 1 Договора о ЕС и ст. 207 Договора, учреждающего Европейское Сообщество. В нем говорится: «Учреждается Комитет по гражданским аспектам урегулирования кризисов, состоящий из представителей государств членов ЕС; Комитет будет действовать как рабочая группа Совета ЕС».

«Совместные действия» используются и для обоснования проведения ЕС операций (гражданских и военных) в рамках ОЕПБО. Примером является военная операция ЕС в бывшей югославской республике Македонии в 2003 г. ${ }^{49}$ и в Боснии и Герцеговине ${ }^{50}$.

Таким образом, невозможно рассматривать все принятые «совместные действия» одинаково. Некоторые решения требуют от государств - членов ЕС осуществить действие, другие просто констатируют или создают юридический факт.

Автор настоящей статьи считает уместным вспомнить о природе «международно-рекомендательных норм», исследованных Р.А. Колодкиным $^{51}$. «Международно-рекомендательные нормы, - пишет он, представляют собой самостоятельный вид международных норм не позволяющий отождествлять их с нормами международного права, нормами морали или характеризовать их как чисто политические нормы. Неприемлемой является и концепция «мягкого права». По своей природе это в основном политические нормы, содержащие некоторый правовой элемент. Содержание международно-рекомендательных норм выражается путем согласования воль государств-членов. Выражение

${ }^{45}$ Council Joint Action 2001/CFSP, Official Journal L/200 от 25.07.2001 г.

${ }^{46}$ Council Joint Action 2005/575/CFSP, Official Journal L/194 от 26.07.2005 г.

${ }^{47}$ Council Joint Action 2004/551/CFSP, Official Journal L/245 от 17.07.2004 г.

${ }^{48}$ Council Decision 2000/354/CFSP, Official Journal L/127 от 27.05.2000 г.

${ }^{49}$ Council Joint Action 2003/92/CFSP, Official Journal L/34 от 11.02.2003 г.

${ }^{50}$ Council Joint Action 2004/570/CFSP, Official Journal L/252 от 28.07.2004 г.

${ }^{51}$ Колодкин Р.А. Международно-рекомендательные нормы: на примере резолюций рекомендаций ГА ООН. Автореф. дис. канд. юрид. наук. М., 1986. вовне рекомендательных норм происходит посредством принятия резолюции ГА ООН, которая рекомендует государствам соответствующие нормы. Будучи самостоятельным регулятором международных отношений, рекомендательные нормы оказывают влияние на формирование международного права, могут создавать канву, рамки для будущего договорного процесса. Рекомендательные нормы влияют на формирование практики и opinio juris. Не легитимируя действий государств, рекомендательные нормы создают, тем не менее, презумпцию правомерности таких действий. Рекомендательные нормы функционируют в рамках основных принципов международного права».

Автор, проводя собственный правовой анализ норм «вторичного права ЕС» и природы актов ОВПБ («общих позиций» и «совместных действий»), в частности, отмечает их следующие характеристики:

- данные нормы принимаются Советом ЕС - институтом международной организации особого рода (sui generis) и являются производными применительно к той или иной норме «первичного права ЕС», т.е основываются на норме учредительного договора (Договора о ЕС), который согласно ст. 2 Венской Конвенции о праве международных договоров является международным соглашением;

- данные нормы в определенной степени регулируют поведение государств-членов ЕС, особенно в контексте согласованности их отношения к тем или иным событиям и ситуациям на международной арене;

- данные нормы имеют сложную функциональную природу, которая остается невыясненной, и различаются по содержанию многообразием составляющих их императивных, а по большей части декларативных норм, норм-утверждений и норм-целей;

- данные нормы могут быть адресованы самому ЕС, государствам членам ЕС либо третьим странам;

- данные нормы призваны подчеркнуть индивидуальность ЕС и правомерность его действий на международной арене и придать действенность проводимой ЕС общей внешней политике и политике безопасности как отдельного вида межправительственного сотрудничества государств - членов ЕС.

Следовательно, нормы ОВПБ ЕС могут быть квалифицированы как международные нормы особого рода (sui generis), правовая природа которых может быть обозначена применительно к правовому режиму ОВПБ. 


\section{Legal Nature of CFSP's Acts in the Acts of the Council of the European Union (Summary)}

Igor A. Kochin*

In his article the author considers it to be vital to dwell on the legal nature of the acts adopted by the Council of EU. In the author's opinion the understanding of the nature of common positions and joint actions of EU is important both from theoretical and practical side especially in the context of developing the framework of future cooperation between EU and Russia in the sphere of common security space. It is known that CFSP is an intergovernmental sphere of cooperation of EU member states and is based on the chapter 5 TEU. Nevertheless the regime of CFSP is also connected with the regime of the external relations of EU which is governed by the separate agreement-Treaty Establishing European Community, the so called Rome Treaty of 1957.The author of the article reminds us that the legal regime of CFSP even if it exists may be considered to have a very complex nature. Analyzing common positions and joint actions of EU as the legal instruments of CFSP the author gives various opinions of European specialists and shows his own knowledge on the subject. He makes an attempt to define categories of common positions of $\mathrm{EU}$ as well as joint actions of EU. Besides the readers have an opportunity to keep track of the essence of these acts adopted by the Council of EU. The author speaks about the addressees and different kinds of norms. He points out that these acts of the Council of EU are binding for EU member states but however member states remain to be the actors in CFSP. It is of great value that the author tries to make up his own conclusions and qualify common positions and joint actions of EU as to be the legal international norms of special nature (sui generis).The article is legally comparative and contemptuous.

* Igor A. Kochin-post-graduate student at the Kazan State University, senior lecturer of the Chair of European and International Law at the Nizhny Novgorod State University, lawyer of the Nizhny Novgorod regional Bar, firm of attorneys №9.

\section{Проблемы реализации Директивы Европейского Совета и Европейского Парламента 90/314/ЕЕС о комплексных турах, путешествиях и отдыхе}

\author{
Хамова Ю.А.*
}

Для 80-х годов XX века характерен всплеск международного массового туризма. Особенно это касается стран Европейского Сообщества. В связи с тем, что стоимость группового обслуживания ниже за счет скидок предоставляемых гостиничными предприятиями, увеличивается процент группового туризма.

Однако к 80-м годам законодательство стран - членов Сообщества в области туризма неодинаково регулировало многие вопросы. Например, в Великобритании вообще не было специальных норм, регулирующих отношения в сфере туризма. К таким отношениям применялись общие положения контрактного права ${ }^{1}$. Гарантийные туристические фонды существовали лишь в некоторых странах Европейского Сообщества (например, в Дании ${ }^{2}$, Ирландии ${ }^{3}$ ). При этом право Европейских Сообществ не содержало положений о защите туристов, деятельности туроператоров/турагентов. Такое положение создавало препятствия для свободы оказания услуг, конкуренции между туроператорами, учрежденными в различных государствах - членах Сообщества, защиты туристами своих прав. Как следствие, суды государств - членов Сообщества были завалены исками от туристов по поводу неисполнения/ненадлежащего исполнения турфирмами своих обязательств ${ }^{4}$.

Первыми забили тревогу представители юридической науки Великобритании. Так, профессор Д. Грант отмечал, что отсутствие едино-

"Хамова Юлия Александровна - аспирант кафедры международного и европейского права Воронежского государственого университета.

${ }^{1}$ European Travel Law / Zahd Yaqub, Becket Bedford. John Wiley\&Sons Ltd., 1997. P. 529. ${ }^{2}$ В Дании гарантийный фонд был учрежден еще в 1986 году законом № 104 от 28.02.1986, который был изменен Актом № 454 от 30.06.1993. В 1997 году был учрежден новый туристический гарантийный фонд Актом № 315 от 14.05.1997.

${ }^{3}$ Tour Operators and Travel Agents (Bonding) Regulations 1983 (S.I. № 102 of 1983); Travellers' Protection Fund Regulations 1983 (S.I. № 103 of 1983).

${ }^{4}$ По данным Holiday travel watch, $71 \%$ покупателей комплексных туров в Великобритании обращались с жалобами в 1985 году. http://www.holidaytravelwatch.co.uk 